\title{
ビデオ画像解析に基づく綾里湾白浜海岸に集中した 津波外力場特性の分析
}

\author{
Video Image-Based Analysis of Concentrating Tsunami Dynamics on Shirahama Beach \\ in Ryori Bay
}

\author{
山中悠資 ${ }^{1} \cdot$ 田島芳満 ${ }^{2} \cdot$ 佐藤愼司 $^{3}$ \\ Yusuke YAMANAKA, Yoshimitsu TAJIMA and Shinji SATO
}

\begin{abstract}
The 2011 Tohoku earthquake tsunami hit wide stretch of the Pacific coast of Japan and measured tsunami inundation heights showed significant variations even along the coast line within the same bay. Lack of quantitative data of tsunami dynamics around the nearshore and inundating area makes it difficult to fully understand actual behaviors of tsunami. This study focused on the analysis of video imagery taken at Shirahama Beach in Ryori Bay, where locally concentrating tsunami inundation height was also observed. Developed analysis system enabled us to quantify the time-varying surface water fluctuations and surface water velocities. It was found through the analysis that shorter wave fluctuations excited around the nearshore breakwaters appear to have significant impacts on such locally concentrating tsunami dynamics.
\end{abstract}

\section{1. はじめに}

2011 年 3 月 11 日 14 時 46 分に発生した東日本大震災は 大規模な津波を引き起こし，東北地方太平洋沿岸を中心 に甚大な被害を及ぼした。東北地方太平洋沖地震津波合 同調査グループ（2011）による津波痕跡調查結果による と，この津波の痕跡は同じ湾内であっても痕跡高が大き く異なる分布を有していたことがわかった。このような 沿岸部や浸水域に扔ける津波の局所集中特性は，インド 洋津波やカトリーナによる高潮による被災調査結果等に おいても指摘されているものの（例えば鯉渕ら，2005； 田島ら，2006）, 実際の汇濫時における定量的デー夕の 不足によりその詳細なメカニズムを実証的に解明する研 究成果は得られていないのが現状である. 一方で, 東日 本大震災による津波の挙動はビデオカメラ等により多く のデー夕が残されており，沿岸部における津波挙動の実 証的理解の飛躍的な進展が期待される.

岩手県大船渡市三陸町に位置する綾里湾では, 他の地 点と同様に来襲した津波が局所集中する傾向が見られた. 特に湾奥の白浜海岸においては, 漁港背後域である南側 斜面周辺で集中的に高い津波痕跡高が計測された。また， 漁港施設や消波構造物の倒壞・損壊も同地点において集 中的に見られた。この白浜海岸においても津波来襲時の 様子がビデオ画像で捉えられている．本研究ではこの白
1 学生会員
東京大学大学院工学系研究科社会基盤学
2 正会員 Ph.D. 専攻
3 フェロー 工博
東京大学准教授大学院工学系研究科社会 基盤学専攻 東京大学教授大学院工学系研究科社会基 盤学専攻

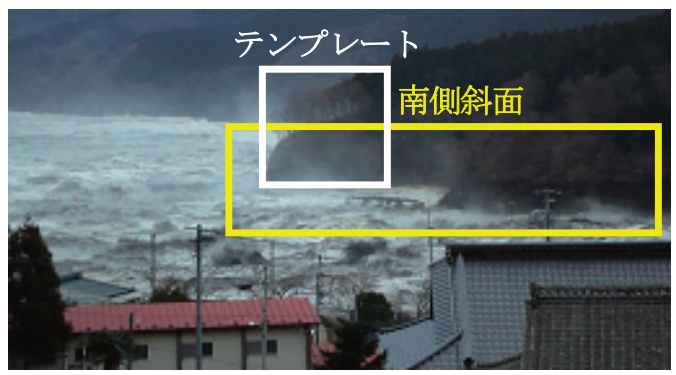

写真-1 撮影されたビデオ画像の一部

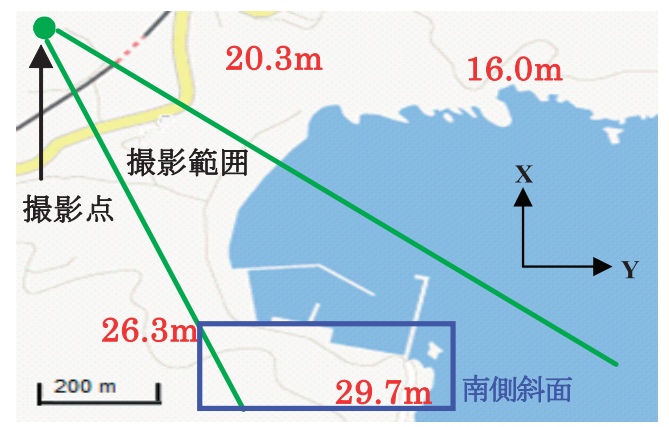

図-1 綾里湾の平面図と津波痕跡高及びカメラ撮影点

浜海岸において撮影されたビデオ画像（写真-1）に焦点 をあてて津波の挙動を可能な限り定量的に抽出し, その 特徵を把握し記述することを研究の目的とする.

\section{2. ビデオ画像の補正}

デジタルビデオカメラによって記録された映像から津 波の定量的な情報を抽出するため, まず映像から $1 / 30$ 秒 間隔で連続する静止画像群を取り出した。定点観測カメ ラによる画角が固定された連続静止画像に基づく沿岸域 


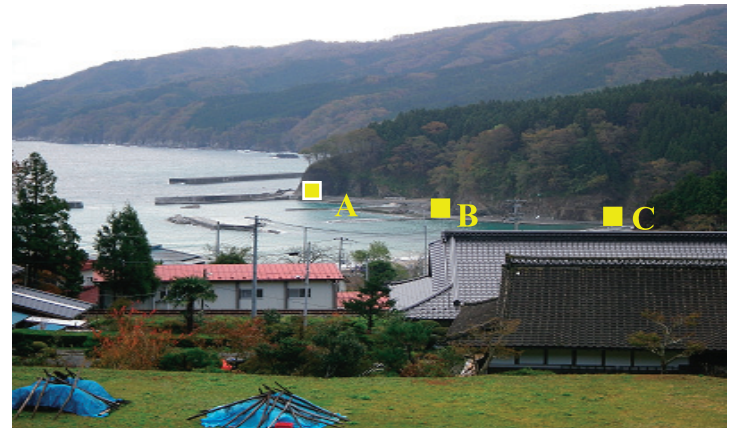

写真-2 静止画像 $\mathrm{A}$

での定量的なデー夕の抽出は既にいくつかの研究事例が あるが（例えば田島ら，2008）, 本研究で対象としたビデ 才画像は津波来襲時に避難しながら撮影されたもので, 手ブレによる画角の変化が著しく，そのままでは定量デ 一夕の抽出が困難であった。 そこで, 本研究では以下の 手順で連続静止画像の補正を行なった。まず取り出した 連続静止画像をそれぞれ輝度值の平面分布に变換し，こ れらの画像群の中から補正のための基準静止画像 1 枚を 選定した. 次に連続静止画像間のマッチングに適する固 定物体を含む領域（テンプレート）を決定し，補正する 画像を平行移動・回転させながら, テンプレート内の輝 度值分布が基準画像のそれと最も良く適合する位置を正 規化相互相関法により求めた。なお，テンプレートには 写真-1に示した南側斜面の一部を指定した。これにより 求まった移動量及び回転量に基づき, 各画像における画 素座標を変換し, 連続した補正画像群を作成した。

\section{3. 二段階座標変換による実座標系の推定}

次に補正後の連続静止画像群に対して幾何的な座標変 換を施すことにより，画素座標に基づく実座標推定を試 みた。津波来襲時のビデオ画像からは座標変換に必要な 実座標情報が既知である点を見出すことが困難であった ため, 本研究ではビデオ画像が撮影された地点とほぼ同 じ地点から静止画像 $\mathrm{A}$ （写真-2）を改めて撮影し，この 座標を介した以下に整理する二段階の座標変換を行うこ とによって実座標の推定を試みた。

まず手ブレ補正時の基準画像内において, 静止画像 $\mathrm{A}$ と共通し, かつ特徵的な点を基準点として20点選定した. これらの基準点の選定時には, これらが画像内にバラン ス良く分布することや, 静止画像 $\mathrm{A}$ 取得時と津波来襲時 で位置が変化していないと考えられることを選定条件と した．次に選定したそれぞれの基準点に対応する点を静 止画像 $\mathrm{A}$ の中から抽出し, 両画像における基準点の画素 情報に基づき，田島ら（2008）と同様の手法を用いて両 画像の位置関係を表すための座標変換パラメー夕を最小 自乗法に基づき推定した。これにより，ビデオ画像内の
任意の画素座標と対応する静止画像 Aの画素座標が得ら れる. 次に, 静止画像 $\mathrm{A}$ のから現地測量によって得ら れている，実座標が既知である9点を選定した。これらの 基準点情報に基づいて同様の座標変換パラメー夕を抽出 した. ここで, 座標変換式は平面から平面への変換式で あるため, 静止画像 $\mathrm{A} の$ 任意の画素座標に加えて実座標 系での任意の平面を指定すれば, その平面上での座標を 求めることができる．例えば標高Zを指定すれば，その水 平面である $(\mathrm{X}, \mathrm{Y})$ 平面座標上の座標が推定可能となる。

\section{4. 実座標系の推定誤差}

ここでは, 開発したビデオ画像に基づく実座標推定シ ステムの妥当性を検証する. 本研究ではビデオ画像から 直接実座標を推定することが困難であったため, (1)ビデ オ画像の手ブレを補正し, (2)補正後画像と対応する静止 画像Aの画素座標を求め, (3)静止画像Aの座標から実座 標を推定する三段階の計算を実施しており，それぞれの 段階における誤差を把握する必要がある。

まず手ブレ補正の誤差については，手ブレ補正後の静 止画像群内で, 特徽的でかつ位置が変わらないと思われ る3 点を選定し, それぞれの画素座標の rms 誤差を求め た. その結果, 3 点での $\mathrm{rms}$ 誤差の平均值は, 画像の画素 座標U（横方向）およびV(縦方向）の方向でそれぞれ 3.8 ピクセル，4.6ピクセルであった。

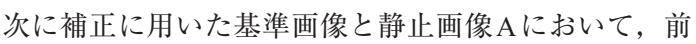
節で選定した20の基準点に対してその推定誤差を算定し たそその結果, 20 点における $\mathrm{rms}$ 誤差の平均值は 0.9 ピク セルであった。

最後に静止画像 $\mathrm{A}$ に基づく実座標系の推定誤差を検証 した，誤差の検証には，座標変換パラメータを抽出する 際に選定した静止画像A内に抢ける7点を対象とし, そ れぞれ画素座標から座標変換を用いて指定した実座標と 現地調査時に測量した実座標との差を比較した。

まずビデオ画像から水位デー夕を抽出することを念頭 に置き, 座標変換式と画素座標に基づく標高 Zの推定誤 差を検証した。画素座標に加えて実座標（X,Y,Z）のい ずれかの成分を指定すれば残りの 2 成分の推定が可能で あるが，逆に任意の2成分 $(\mathrm{X}, \mathrm{Y})$ と画素座標は抽出し た座標変換式を必ずしも満たさない. そのため, 本研究 では指定した画素座標と任意の Z に基づく推定座標 $\left(\mathrm{X}^{\prime}, \mathrm{Y}^{\prime}\right)$ と指定した $(\mathrm{X}, \mathrm{Y})$ との距離（誤差）を求め, この距離を最小とするZを推定值として定めた。この時, 推定したZと計測した標高との誤差は7点の rms 誤差で約 $5.1 \mathrm{~cm}$ であった。逆に, 標高Zに実測值を与えて推定した $\mathrm{X}$ 及びYの $\mathrm{rms}$ 誤差は, それぞれ $36.5 \mathrm{~cm}, 50.0 \mathrm{~cm}$ であっ た。これらの結果から, 静止画像 Aに扔ける画素座標や 実座標上のいずれか 1 成分が正しく与えられれば, 残り 
表-1 与条件誤差によるパラメータの誤差感度

\begin{tabular}{|c|c|c|c|}
\hline 与条件誤差 & $\begin{array}{c}\text { 推定誤差 } \\
(\mathrm{X})\end{array}$ & $\begin{array}{c}\text { 推定誤差 } \\
(\mathrm{Y})\end{array}$ & $\begin{array}{c}\text { 推定誤差 } \\
(\mathrm{Z})\end{array}$ \\
\hline 1pixel (U 方向) & $0.070 \mathrm{~m}$ & $0.072 \mathrm{~m}$ & $0.016 \mathrm{~m}$ \\
\hline 1pixel (V 方向) & $1.337 \mathrm{~m}$ & $1.134 \mathrm{~m}$ & $0.102 \mathrm{~m}$ \\
\hline $1 \mathrm{~m} \quad(\mathrm{X}$ 方向 $)$ & - & - & $0.041 \mathrm{~m}$ \\
\hline $1 \mathrm{~m} \quad(\mathrm{Y}$ 方向 $)$ & - & - & $0.042 \mathrm{~m}$ \\
\hline $1 \mathrm{~m} \quad(\mathrm{Z}$ 方向) & $13.11 \mathrm{~m}$ & $11.13 \mathrm{~m}$ & - \\
\hline
\end{tabular}

の2つの実座標の推定誤差は十分に小さいものであると 言える.

次に上述した三段階の実座標推定手法のうちの最初の 二段階である，ビデオ画像から静止画像A上での画素座 標を求める段階における推定誤差や，与条件として与え る実座標上の 1 成分の誤差による，実座標推定精度に対 する感度分析を行なった，与条件誤差の感度が最も高い のは実座標上で観測点から最も離れている点であると考 えられるため, ここでは写真-2に示した南側斜面の湾口 付近の点 $\mathrm{A}$ に対して誤差の感度分析を行なった。分析は 与条件とする画素座標 (U,V) と実座標（X,Y,Z）のいず

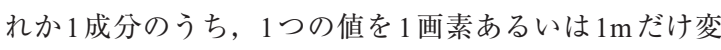
化させ, その時の残りの実座標の推定值の変化量を求め た (表-1).

表-1より, 与条件誤差に対するZ の画素座標 Vで最も大きいが，それでも約 $10 \mathrm{~cm} /$ pixelで あり, 標高の推定精度の信頼性は比較的高いと判断する ことができる.また最初の二段階における画素座標の推 定誤差は最大で約 4.7 ピクセル (U), 約 5.5 ピクセル (V) であることから, 本研究におけるZの推定誤差は最大で $60 \mathrm{~cm}$ 程度となることが予想される。

一方，X及びYの推定誤差は，与条件Uの誤差による

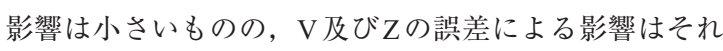
ぞれ 1 画素に対して $1 \mathrm{~m}$ 以上， $1 \mathrm{~m}$ の誤差に対して $10 \mathrm{~m}$ 以 上と大きかった。 以上より，推定された標高座標 $\mathrm{Z} に つ$ いては誤差 $10 \mathrm{~cm}$ 程度以下の精度が期待できるのに対し て, 水平座標 $(\mathrm{X}, \mathrm{Y})$ の絶対位置については $10 \mathrm{~m}$ 程度の 誤差がある可能性があるため注意が必要である。一方, 例えば漂流物の追跡から流速を推定する際には移動距離 が重要であり, 絶対位置の推定よりも相対的位置関係の 推定精度が重要となる。そこで静止画像A内の白浜海岸 の水面上の 4 点を選定し, 与条件として Zを変化させた 時, 推定された 4 点の水平距離がどの程度変化するか計 算した。 その結果，与条件 Zの值が $1 \mathrm{~m}$ 大きくなると，X 方向及びY方向の各点間距離は $2.0 \%$ 程度減少した.これ は与条件 Zが $+1 \mathrm{~m}$ の誤差を持つ場合，例えば実点間距離 $100 \mathrm{~m}$ が $98 \mathrm{~m}$ と推定されるということである.したがって， $(\mathrm{X}, \mathrm{Y})$ の推定值の絶対位置の推定誤差は大きいものの,

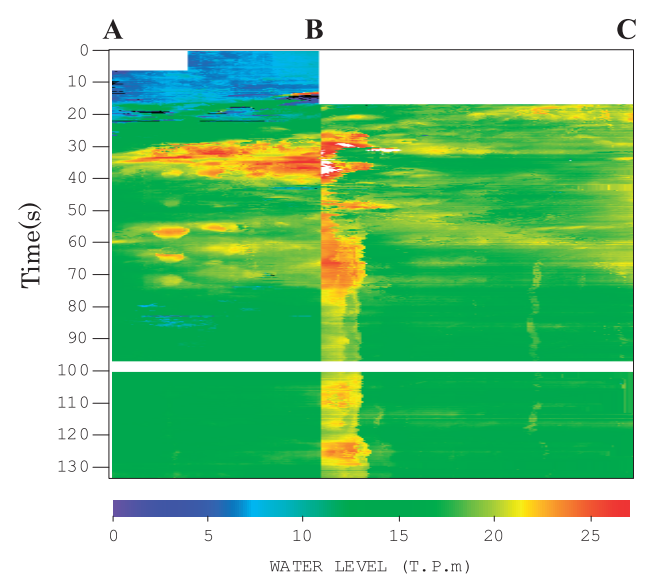

図-2 推定した南側斜面の水位

相対位置の推定誤差は比較的小さいものであると言える.

\section{5. ビデオ情報に基づく定量情報の抽出}

\section{（1）南側斜面における水位の推定}

手ブレ補正後静止画像群から南側斜面の画像内の水面 位置を抽出し，それを与条件として与えることで時々 刻々の水位を推定した. 推定手順を以下に示す。まず輝 度值の勾配べクトルとその閾值を用いることで水面位置 の画素座標を抽出した。水位の推定には前節で示した方 法を用いたが，それには対応する水平座標を与条件とし て与える必要がある. 本研究では静止画像A内の南側斜 面に沿ってGPSで測量した水平座標群を用い, これら 各々の点から実座標のZ軸（鉛直方向）に沿った線を伸 ばし，この線と抽出した斜面と水面の境界線との交点に おけるZ座標を水面高さとして求めた。ここで, 水面境 界は斜面上に位置しているため, 実際にはGPSで計測し た水平位置とはズレがある。画像とほぼ正対する斜面の 勾配を $30^{\circ}$ と, 計測地点と水面との標高差を勘案すると 水平座標のズレは $15 \mathrm{~m}$ 程度であると考えられ，このとき のZ座標の䛊差は表-1 と同様の操作を行うことにより $1 \mathrm{~m}$ 程度過大となることがわかった．また湾口と湾奥では撮 影地点からの距離が異なるため, 斜面上の水平座標推定 誤差による水位の誤差は, 湾奥の方が湾口よりも数十 $\mathrm{cm}$ 程度高くなる可能性があることにも留意する必要がある.

南側斜面における推定した水位の時間変化図を図-2に 示す. 図-2の横軸は斜面に沿った水平方向距離, 縦軸は 時間経過（下向きを正）を，色が推定水位を表している. 図中の A, B, C は写真-2に示した斜面に沿った位置で, $\mathrm{B}$ 点は撮影点から南側斜面を見たときの画面手前の斜面 と画面奥の斜面の境界位置である.A-B間は画面奥の斜 面上の水位， B-C間は画面手前の斜面上の水位を表すた め，A-B間と B-C間の境界は不連続である。ここで，時 
間はビデオ撮影開始からの時間を表す。図-2では, 水位 がピークに達した 30 秒付近以後で周期 8 秒程度の水面変 動が見られる。また，この変動はA-B 間でほぼ同位相で 変化しており, 斜面と直行する方向, すなわち沿岸方向 に波が伝播していることがわかった。一方，B-C間では 50 秒から 70 秒にかけて右斜め下に向かって水位のピーク が岸向きに移動している様子も見られた。これらのこと から, 湾口での水位変動は津波の侵入方向と南側斜面に 正対する方向の最低二つのモードを有していたと推察さ れる。また湾奥では津波による周期の長い水面変動が卓 越し，重複波を形成していたようである。さらに，A-B 間で見られたような短周期の水面変動が， B-C間でも同 様に見られた。

\section{（2）漂流物の移動方向と移動速度}

ビデオ画像内には漁船のブイなどの漂流物が多数確認 できた.この各漂流物を 0.5 秒間隔で追跡することによっ て, 白浜海岸内での波や流れ場の推定を試みた。漂流物 平面座標を推定するには，与条件として漂流物の画素座 標と水面標高を与える必要がある．標高は前節で求めた C地点における水位デー夕（図-3）を平滑化して与えた.

推定した漂流物の位置，移動方向，移動速度を図-4に 示す. 漂流物の初期位置は赤色で示し, 同一漂流物の平 面座標は直線で結んでいる。 また，図-3の水位がピーク となる時間（ $\mathrm{t}=35 \mathrm{~s} ）$ を境界としてピーク来襲前後の二つ の時間帯に分割し，それぞれの時間帯における漂流物の 追跡結果を表示した。図-4より，ピーク前の漂流物はそ
のほとんどが津波の侵入方向と一致した方向に移動して いるが，明らかに北から南に向いて移動している漂流物 （No.5,7,8）も見られた. またそのような移動方向を示し た漂流物は水位がピークに達する時間带に集中している ことから, 水位のピーク近傍の時間帯で湾内の津波が既 に重複波を形成していたことや，周期の短い水面変動が 漂流物の移動特性に影響を及ぼしていたことが考えられ る.ささらに, ピーク前の漂流物の平均移動速度はほとん

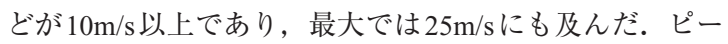
ク後には漂流物の移動方向は場所によって異なってお り，ピーク直後に卓越して見られた周期 8 秒の水面変動 により，移動形態が大きく変化したと考えられ，これは 海岸構造物の存在によって複雑な流れ場が形成されたこ とによるものであると考えられる.

\section{（3）水面上における輝度値の標準偏差}

ビデオ画像では津波来襲時に周期 8 秒程度の激しい水面 変動が見られたが，その大きさは場所や時間により異な っており，これが来襲した津波が局所集中した原因の一 つであると推察される. 本研究では画像内の輝度值の変 化に着目してその水面位置を抽出した竹原ら（2010）の 研究を参考にし, 手ブレ補正後の静止画像の同一画素座 標の輝度值の標準偏差を求め, その平面分布を比較した.

まず全ての手ブレ補正後静止画像の同一画素座標の輝 度值の自乗和を求め, その平均值を求めた. 次に同様に してそれらの輝度值の平均值を求め, その自乗值を求め た。それらの差を2倍して平方根で除したものを輝度值

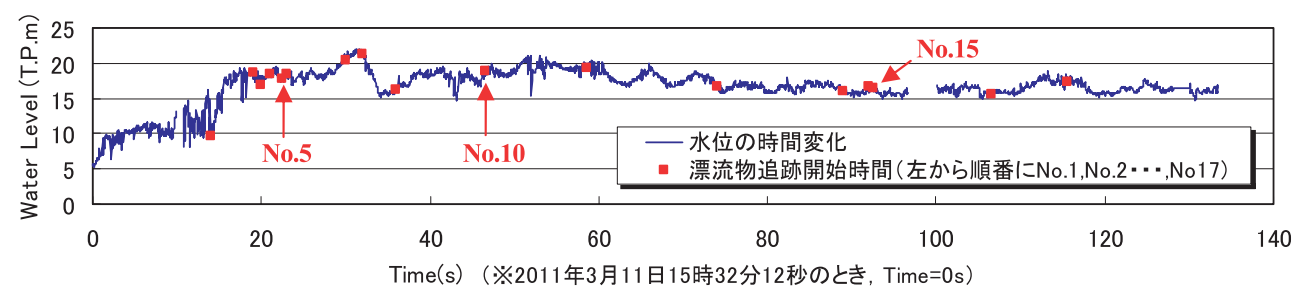

図-3 湾奥 (C 点付近) 地点の水位

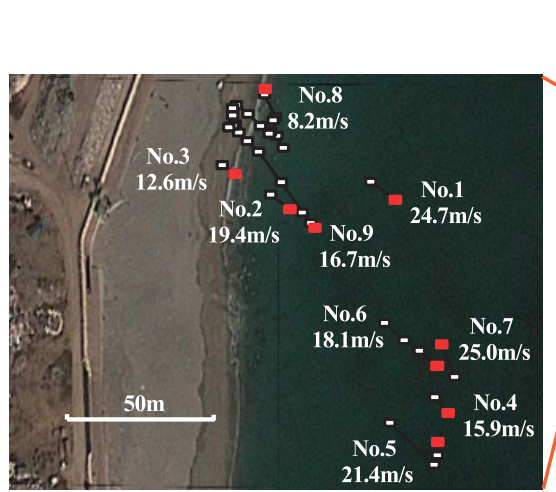

(a) 水位のピーク前

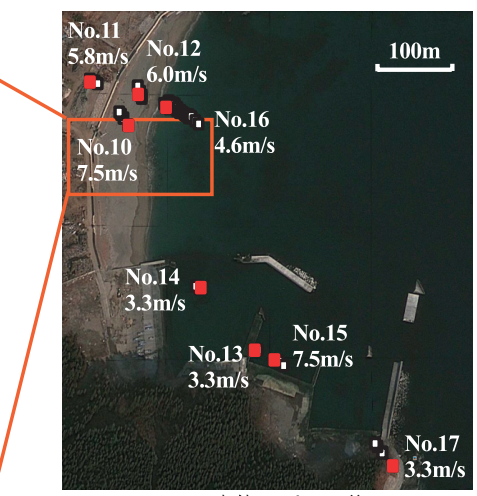

(b) 水位のピーク後

図-4 漂流物の位置 · 移動方向 $\cdot$ 移動速度 


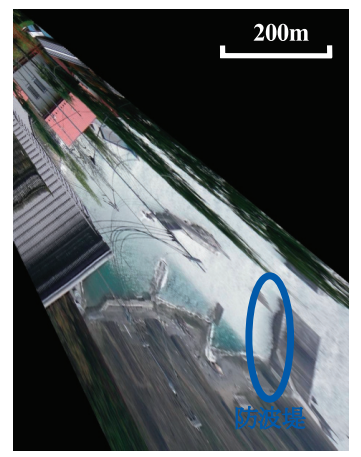

(a) 平面図(静止画像 A)

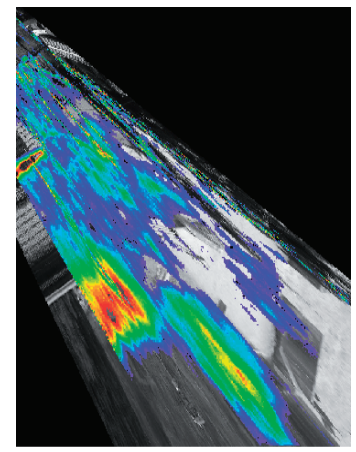

(b) 水位のピーク前

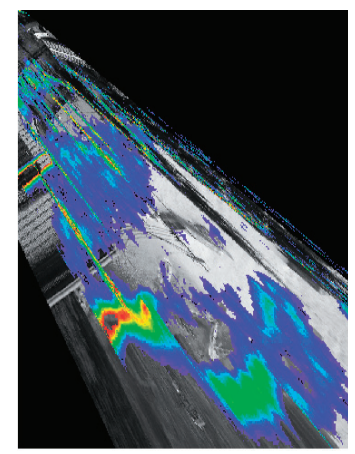

(c) 水位のピーク後

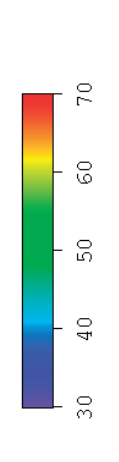

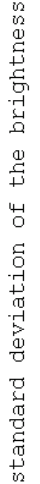

図-5 水面において時間変化する輝度值の標準偏差の平面分布（座標変換により描画）

の標準偏差と定義した。図-5（b) より，相対的に水深が 浅かったと考えられる南側斜面周辺においては標準偏差 が大きくなる傾向が見られる.これは砕波を伴う波の浅 水変形によるものであると考えられる。また津波が防波 堤を越流するとき, 防波堤の裏側は剥離渦によって激し い水面変動が生じると思われるが，図-5 (b) の防波堤付 近では輝度值の標準偏差が相対的に小さくなった. 一方, 図-5 (c) では同地点周辺での標準偏差が大きくなる傾向が 見られ，ピークの前後でその平面分布が大きく異なった. これには，ピーク来週時に発達した短周期波と周期の長 い津波による流れとの干渉や，白浜海岸における重複波 の重畳など様々な要因が考えられるが，その詳細な分析 については今後の課題である.さらに，防波堤付近では 水深が急激に小さくなるため, その周辺の水面変動は激 しくなると予想されたが，水位のピーク前では水面は比 較的静穏で, ピーク後に水面変動が激しくなるという結 果となった。このような結果が得られた理由として，湾 内では津波による長周期の波に加えて比較的短周期の波 が卓越して生じていた。この長周期波と短周期波が関係 する非常に複雑な波・流れ場が形成されたために, 従来 の長波理論では説明できない挙動が湾内で生じたものと 思われる.この短周期波が卓越することによって生じて いた津波の挙動は，防波堤を破壊・損壊させた力を増幅 させた可能性があり, さらに詳細に分析する必要がある.

\section{6. まとめ}

綾里湾白浜海岸において撮影された津波来襲時のビデ 才画像から定量的な情報を抽出した. その結果, 津波に よる長周期の水位変動は湾奥ほど高くなっていたこと, 周期 8 秒程度の激しい水面変動が南側斜面に沿ってほほ 同位相で見られ，この周期の波は斜面に直交する方向に 伝播していたこと，水位のピーク前では津波の侵入方向 と一致して $10 \mathrm{~m} / \mathrm{s}$ 以上の漂流物の移動速度が推定された のに対し，ピーク後では場所によってその移動方向が異
なっていたことなどがわかった。ささらに水面変動の激し さを表す指標として, 同一地点における画像の輝度值の 時間変化から，その標準偏差を算定して比較した結果， ピーク前には南側斜面や海岸堤防周辺で輝度值の標準偏 差が大きかったのに対して，このような領域は，ピーク 後には漁港防波堤周辺のみに限定される傾向が見られ た。このような現象が生じた原因は短周期波の存在にあ ると考えられ，これが長周期波として作用する津波波力 に加えて構造物の倒壊・損壊に関与した可能性が指摘で き, 今後さらに詳細な分析を行う予定である.

謝辞: 平成 23 年 3 月末に行われた津波痕跡調査で現地の 住民の方に貴重なビデオ画像を提供していただいた。こ こに記して謝意を表する。また，本研究の成果はJST平 成 23 年度J-RAPID プログラムによる研究成果の一部であ ることを付記する.

\section{参 考 文 献}

鯉渕幸生 - 本田隆英 - Thisara WELHENA - RANASINGHE · 佐藤壃司（2005）：インド洋地震津波によるスリランカ南 西部海岸の被害集中機構, 海岸工学論文集, 第 52 巻, pp1411-1415

酒井哲郎（1975）：傾斜した海底を有する湾における長波の湾 水振動, 第22回海岸工学講演会論文集, pp.279-284

竹原幸生, 江藤剛治（2010）：風波砕波下における渦運動の PTV 計測, ながれ, 日本流体力学会誌, 29（6), pp.437439

田島芳満 ·佐藤愼司・藤原弘和（2006）：Hurricane Katrinaに よるBiloxi周辺の高潮被害分布とその外力特性の検証, 海 岸工学論文集, 第 53 巻, pp.406-410

田島芳満 · 高川智博 - 浅野泰史 · 佐藤㯖司 · 武若 聡 （2008）：特性の異なる二つの台風による天竜川河口砂州 の大規模変形, 海岸工学論文集, 第 55 巻, pp646-650

田島芳満 · 丹治雄一 - 三宅健一 - 加藤広之 ・ 中山哲嚴 (2011)：連続続静止画像に基づく島田川河口部における 地形変動特性の分析, 土木学会論文集 B3 (海洋開発), Vol.67, ppI_1045-I_1060

東北地方太平洋沖地震津波合同調査グループによる速報值 (http://www.coastal.jp/ttjt/，2011 年4月 18 日参照) 